\title{
Porcine Parvovirus Infection in Boars in the Czech Republic
}

\author{
J. BICAN, M. SVOBODA, J. DRÁBEK \\ Clinic of Pig Diseases, Faculty of Veterinary Medicine, University of Veterinary
} and Pharmaceutical Sciences, Brno, Czech Republic

Received May 5, 2001

Accepted February 13, 2002

\section{Abstract}

Bican J., M. Svoboda, J. Drábek: Porcine Parvovirus Infection in Boars in the Czech Republic. Acta Vet. Brno 2002, 71: 45-49.

Boars may play a significant role in dissemination of parvovirus (PPV). During acute infection the virus is shed by various routes, including semen. The objective of this study was to evaluate occurrence of natural infection with porcine parvovirus in boars in the Czech Republic by serological examination. A total number of 800 sera from boars of 42 herds were collected. The sampling was made between January and December 1999. All serum samples were tested for porcine parvovirus (PPV) antibodies by haemagglutination inhibition test (HIT). In 31 herds, boars have never been vaccinated to PPV. In 11 herds boars were regularly vaccinated to PPV. A pig was considered infected with HI titres higher than 1:256 in non-vaccinated herds. In vaccinated herds non-infected boars could be determined only with titres equal to or lower than 1: 256 . Infection with porcine parvovirus was detected in $80.6 \%$ of non-vaccinated herds. Non-infected boars were only found in $18.2 \%$ of vaccinated herds. From the total number of 528 boars tested in nonvaccinated herds $60.8 \%$ were detected as infected. From the total number of 272 boars tested in vaccinated herds $37.5 \%$ were found to be non-infected. Our results indicate that infection with porcine parvovirus is widespread in boars in the Czech Republic. With regard to the possibility of excretion of parvovirus in semen it is obvious that boars can play an important role in transmission of parvovirus in pig herds in the Czech Republic.

Pig herds, haemagglutination inhibition test, haemagglutination inhibition titer, vaccinated herds, non-vaccinated herds.

Infection with porcine parvovirus is generally believed to be enzootic on pig farms over the world (Vanniers et al. 1984). Porcine parvovirus (PPV) causes reproductive failure of swine characterized by embryonic and fetal infection and death, usually in absence of outward maternal clinical signs (Mengeling 1999). The infection has been associated mainly with reproductive failure such as return to oestrus, fetal death, mumification and abortion (Bowkamp and Wellenberg 1990). Gilts are protected from infection by colostral antibodies during 4 - 6 months after birth (Paul et al. 1982). Thereafter they are fully susceptible to infection. At the same time gilts are first used in reproduction. In enzootically infected populations most sows experience infection and develop immunity. Animals at risk are young gilts introduced to infected environment at the age of 7-8 months. The most common routes of infection for postnatal and prenatal pigs are oronasal and transplacental, respectively (Mengeling 1999). Contaminated premises are probably major reservoirs of PPV. The virus is thermostable, it is resistant to many common disinfectants (Brown 1981), and may remain infectious for months in secretions and excretions from acutely infected pigs (Mengeling 1999).

The boar may play a significant role in dissemination of PPV at a critical time. During acute infection the virus is shed by various routes, including semen, and the isolation of PPV from semen of naturally infected boars has been reported (Mc Adaragh and Anderson 1975). Semen may also be contaminated externally, as for example with virus containing

Address for correspondence:

Address for correspondence:

University of Veterinary and Pharmaceutical Sciences

University of Veterinary and

Czech Republic
Phone : +420541562433

Phone : +420541562433
Fax : + 420 5748841

e-mail : svobod 741

http://www.vfu.cz/acta-vet/actavet.htm 
feces, or within the male reproductive tract (Mengeling 1999). Porcine parvovirus DNA was determined to be bound to spermatozoa that had been incubated in vitro with PPV (Gradil et al. 1990). There is no evidence that either fertility or libido of boars is altered by infection with PPV (Thacker et al. 1987). Results obtained by Nielsen et al. (1991) strongly indicate that intrauterine spread of PPV is a route of transmission of the virus between pig foetuses. When only part of a litter is infected transplacentally, as is often the case, one or more littermates are frequently infected by subsequent intrauterine spread of virus. The same would apply if initial infection were through contaminated semen (Mengeling 1999). Exclusion of parvovirus from semen is especially critical because of its ability to survive in frozen semen (Thacker et al. 1984). The use of artificial insemination creates a mode of disease transmission between farms.

\section{Materials and Methods}

The sampling was made in 42 pig herds between January and December 1999. Serum samples were collected from boars and the total number of serum samples was 800 . The pig herds used in this study were located all over the Czech Republic. In North Bohemia - 3 herds, in West Bohemia - 8, in South Bohemia - 8, in Middle Bohemia, - 3, in East Bohemia - 9, in South Moravia - 8, in North Moravia - 3. In 31 herds boars have never been vaccinated. In 11 herds boars were regularly vaccinated against PPV. In non-vaccinated and vaccinated herds 528 and 272 boars were tested, respectively. Boars were vaccinated twice 21 days apart with inactivated vaccine (Bioveta, Ivanovice na Hané - min. 256 HA per dose). Revaccination was done after six months. The same vaccine was used in all herds. Boars were vaccinated for the first time as early as at 7 months of age. All serum samples were tested for porcine parvovirus (PPV) antibodies by haemagglutination inhibition test (HIT).

The boars were bled by vena cava cranialis puncture. Then, samples were centrifuged and sera were aliquoted and stored at $-20^{\circ} \mathrm{C}$ until use. The serum samples to be tested for PPV antibodies were heat-inactivated at $56^{0} \mathrm{C}$ for 30 min, then treated with kaolin $25 \%$ in PBS and guinea pigs erythrocytes $3 \%$ in PBS to remove non-specific inhibitors of HA. Haemagglutination inhibition test was carried out on 96 - U-bottom plates. Two-fold dilution of the treated serum were made in $50 \mu \mathrm{l}$ volumes of PBS ( $\mathrm{pH} 7.2$ ). $50 \mu \mathrm{l}$ of viral suspension containing 8 haemagglutinating units of PPV (CAPM - V - 198 - strain S - 27) was added to each dilution. After incubating for $2 \mathrm{~h}$ at $37^{\circ} \mathrm{C}, 100 \mu \mathrm{l}$ of 0.5 $\%$ suspension of guinea pig erythrocytes was added and the plates were incubated at room temperature for additional 1.5-2 h. Appropriate serum, virus and erythrocytes controls were added to the test. The titre was expressed as the reciprocal of the highest dilution at which haemagglutination was inhibited. According to literature a pig was considered to be infected with HI titres higher than 1:256 in non-vaccinated herd. In both vaccinated and nonvaccinated herds pigs with titres equal to or lower than 1: 256 were considered to be non-infected.

The following data were collected for each herd. For each herd the occurrence of 8 different titres was summarized. Overall prevalence of each titre was calculated.

\section{Results}

Based on the results of serological examination, boars were divided into 8 different groups. Each group represents different HIT titer: $\mathrm{a}<1: 256, \mathrm{~b}=1: 256, \mathrm{c}=1: 512, \mathrm{~d}=1$ : $1024, \mathrm{e}=1: 2048, \mathrm{f}=1: 4096, \mathrm{~g}=1: 8192, \mathrm{~h}=1: 16384, \mathrm{i}=1: 32768$.

The overall results for boars in non-vaccinated herds are given in Table 1, for boars in vaccinated herds in Table 2. Results in the tables are expressed as numbers of boars for each titer in one herd. A total of 31 non-vaccinated herds were studied and in 25 of them $(80.6 \%)$ natural infection with porcine parvovirus was detected showing at least one boar with titer higher than 1: 256. A total of 11 vaccinated herds were examined and parvovirus negative boars were detected in 2 of them $(18.2 \%)$ having all boars with titre equal to or lower than 1: 256 . From the total number of boars (528) tested in non-vaccinated herds 321 boars $(60.8 \%)$ were detected as infected. From the total number of boars (272) tested in vaccinated herds 102 boars $(37.5 \%)$ were found to be non-infected.

\section{Discussion}

An unvaccinated pig with HIT titres more than 256 is considered to be infected (seropositive) (Grimoldi et al. 1998; Huysman et al. 1992; Sorensen et al. 1988). Literature on the immune response of seronegative pigs to inactivated vaccines gives different 
Table 1

Prevalence of antibodies against PPV in boars in non-vaccinated herds (HIT)

\begin{tabular}{|c|c|c|c|c|c|c|c|c|c|c|c|}
\hline \multicolumn{2}{|c|}{ Herd } & $\mathrm{n}$ & $1<256$ & $1: 256$ & $1: 512$ & $1: 1024$ & $1: 2048$ & $1: 4096$ & $1: 8192$ & $1: 16384$ & $1: 32768$ \\
\hline 1 & $\mathrm{I}$ & 19 & 5 & 4 & 1 & 1 & 1 & 0 & 0 & 6 & 1 \\
\hline 2 & $\mathrm{I}$ & 3 & 1 & 1 & - & - & - & - & 1 & - & - \\
\hline 3 & $\mathrm{I}$ & 95 & 15 & 4 & 2 & 7 & 1 & 4 & 9 & 39 & 14 \\
\hline 4 & $\mathrm{I}$ & 3 & - & - & - & - & - & - & - & 2 & 1 \\
\hline 5 & $\mathrm{I}$ & 4 & 3 & - & - & - & - & - & - & 1 & - \\
\hline 6 & $\mathrm{I}$ & 14 & 8 & 1 & 2 & 2 & - & - & 1 & - & - \\
\hline 7 & $\mathrm{I}$ & 16 & 11 & - & - & 1 & - & - & 2 & 2 & - \\
\hline 8 & $\mathrm{I}$ & 52 & 5 & 4 & 4 & 11 & 4 & 6 & 3 & 14 & 1 \\
\hline 9 & $\mathrm{I}$ & 17 & 12 & - & - & 1 & - & 1 & - & 2 & 1 \\
\hline 10 & $\mathrm{I}$ & 3 & - & - & - & - & - & - & 2 & 1 & - \\
\hline 11 & $\mathrm{I}$ & 11 & 3 & 2 & 2 & 1 & 2 & - & - & 1 & - \\
\hline 12 & $\mathrm{I}$ & 3 & - & - & - & - & 2 & - & 1 & - & - \\
\hline 13 & $\mathrm{I}$ & 71 & 23 & 10 & 5 & 13 & 3 & 4 & 6 & 7 & - \\
\hline 14 & $\mathrm{~N}$ & 4 & 3 & 1 & - & - & - & - & - & - & - \\
\hline 15 & $\mathrm{I}$ & 21 & 7 & 3 & 2 & 3 & 1 & - & - & 5 & - \\
\hline 16 & $\mathrm{~N}$ & 2 & 1 & 1 & - & - & - & - & - & - & - \\
\hline 17 & $\mathrm{I}$ & 23 & 6 & 3 & 1 & - & - & 5 & 2 & 6 & - \\
\hline 18 & $\mathrm{~N}$ & 5 & 2 & 3 & - & - & - & - & - & - & - \\
\hline 19 & $\mathrm{I}$ & 3 & - & - & - & - & - & - & 1 & 2 & - \\
\hline 20 & $\mathrm{I}$ & 10 & 5 & - & 1 & - & 1 & - & - & 2 & 1 \\
\hline 21 & $\mathrm{I}$ & 4 & - & - & - & - & - & - & 2 & 1 & 1 \\
\hline 22 & $\mathrm{~N}$ & 2 & 2 & - & - & - & - & - & - & - & - \\
\hline 23 & $\mathrm{I}$ & 3 & 1 & - & - & - & - & 1 & 1 & - & - \\
\hline 24 & $\mathrm{I}$ & 7 & - & 2 & 4 & - & - & 1 & - & - & - \\
\hline 25 & $\mathrm{I}$ & 2 & - & - & - & - & - & - & 1 & 1 & - \\
\hline 26 & $\mathrm{~N}$ & 3 & 1 & 2 & - & - & - & - & - & - & - \\
\hline 27 & $\mathrm{I}$ & 36 & 5 & - & 1 & 2 & 1 & 1 & 8 & 16 & 2 \\
\hline 28 & $\mathrm{I}$ & 69 & 22 & 9 & 11 & 3 & 3 & 2 & 5 & 14 & - \\
\hline 29 & $\mathrm{I}$ & 3 & - & - & - & 1 & 1 & - & 1 & - & - \\
\hline 30 & $\mathrm{I}$ & 16 & 10 & 2 & 1 & 2 & 1 & - & - & - & - \\
\hline 31 & $\mathrm{~N}$ & 4 & 2 & 2 & - & - & - & - & - & - & - \\
\hline \multirow{2}{*}{ Total } & 528 & 153 & 54 & 37 & 48 & 21 & 25 & 46 & 122 & 22 \\
\hline
\end{tabular}

Table 2

Prevalence of antibodies against PPV in boars in vaccinated herds ( HIT)

\begin{tabular}{|c|c|c|c|c|c|c|c|c|c|c|c|}
\hline \multicolumn{2}{|c|}{ Herd } & $\mathrm{n}$ & $1<256$ & $1: 256$ & $1: 512$ & $1: 1024$ & $1: 2048$ & $1: 4096$ & $1: 8192$ & $1: 16384$ & $1: 32768$ \\
\hline 1 & - & 101 & 32 & 11 & 5 & 8 & 3 & 5 & 8 & 23 & 6 \\
\hline 2 & $\mathrm{~N}$ & 4 & 4 & - & - & - & - & - & - & - & - \\
\hline 3 & - & 13 & 9 & 2 & 1 & 1 & - & - & - & - & - \\
\hline 4 & $\mathrm{~N}$ & 3 & 2 & 1 & - & - & - & - & - & - & - \\
\hline 5 & - & 4 & - & - & 1 & - & - & - & - & 3 & - \\
\hline 6 & - & 104 & 16 & 11 & 14 & 8 & 16 & 8 & 4 & 25 & 2 \\
\hline 7 & - & 13 & 5 & 3 & 2 & 3 & - & - & - & - & - \\
\hline 8 & - & 20 & - & 2 & 2 & - & - & - & 4 & 10 & 2 \\
\hline 9 & - & 2 & - & - & - & - & - & - & 2 & - & - \\
\hline 10 & - & 4 & 3 & - & 1 & - & - & - & - & - & - \\
\hline 11 & - & 4 & 1 & - & 1 & - & - & 1 & - & 1 & - \\
\hline \multicolumn{2}{|c|}{ Total } & 272 & 72 & 30 & 27 & 20 & 19 & 14 & 18 & 62 & 10 \\
& $100 \%$ & $26.5 \%$ & $11 \%$ & $9.9 \%$ & $7.3 \%$ & $7 \%$ & $5.1 \%$ & $6.6 \%$ & $22.8 \%$ & $3.7 \%$ \\
\hline
\end{tabular}

$\mathrm{n}$ - number of boars tested, I - infected, $\mathrm{N}$ - noninfected 
results. According to Sorensen et al. (1988) the immune response depends on amount of inactivated virions presented in the vaccine. For example, Sorensen et al. (1988) reported titres as high as 1:2048, Pye et al. (1990) reported titres as high as 1:512, according to Castro et al. (1992) titres can reach values over 1:640. Therefore in our survey we considered a pig to be infected with $\mathrm{HI}$ titres higher than 1:256 only in non-vaccinated herds. In vaccinated herds a pig with natural parvovirus infection cannot be evaluated accurately. Since initial titres before vaccination are not known, it is not possible to determine exactly naturally infected boars in vaccinated herds. Therefore in vaccinated herds we were able to determine non-infected boars only with titres equal to or lower than 1:256.

This survey showed a range of serological titres. It is interesting to notice a large prevalence of higher titres (see Table 1 and Table 2). Our data are in agreement with findings recorded in porcine parvovirus survey conducted in Argentina (Grimoldi et al. 1998). In this survey $53 \%$ of positive animals had very high titres (1:16384), while the remaining pigs showed lower and variable titres.

Porcine parvovirus is widespread in pigs throughout the world but the reports published on the percentage of seropositive herds and seropositive animals within the herds are variable. Only few reports were published on the percentage of seropositive boars in pig herds. High prevalence of seropositive boars were reported by Krpata (1981) and Jeřábek et al. (1986). Krpata (1981) tested serologically (HIT) 256 boars from 4 artificial insemination (AI) boar centers in the Czech Republic for parvovirus infection. Boars positive for porcine parvovirus were found in all 4 AI boar centers, 170 boars $(66.4 \%)$ were positive, 86 boars (33.6\% ) were negative. In the study conducted by Jeřábek et al. (1986) on 78 boars in 3 herds in the Czech Republic one third (33.3\%) of boars had titres 1: 512 and higher. On the contrary low prevalence of seropositive boars was reported by Sorensen (1982) and Peisak and Vyjcik (1987). Sorensen (1982) in Norway examined at 2 performance test stations 302 boars and at 2 isolation camps 148 boars for antibody to PPV. Seventy six per cent and $97 \%$ of the boars, respectively were found to have low titres or tested negative for PPV antibody. Peisak and Vyjcik (1987) tested 180 boars at AI boar centers in Poland. The average amount of sera with positive titres to PPV was as low as $22.22 \%$ of all responders from large pigs units.

The results of our survey indicate that porcine parvovirus is widespread in boars in the Czech Republic. With regard to the possibility of its excretion in semen it is obvious that boars may play an important role in transmission of parvovirus in pig herds in the country.

\section{Infekce parvovirem prasat u kanců v České republice}

Kanci mohou hrát v šiření parvovirózy prasat důležitou úlohu. Během akutní fáze je virus vylučován různými cestami, včetně semene. Cílem předkládané práce bylo zjistit výskyt přirozené infekce parvovirem prasat u kanců v chovech v České republice. Celkem bylo vyšetřeno 800 kanců pocházejících ze 42 chovů. Odběr vzorků v chovech prasat byl uskutečněn v období od ledna do prosince roku 1999. Krevní séra těchto kanců byla vyšetřena na protilátky proti parvoviru prasat hemaglutinačně inhibičním testem (HIT). V 31 testovaných chovech nebyla $\mathrm{v}$ předchozím období nikdy provedena vakcinace kanců proti parvoviróze, v 11 chovech byli kanci pravidelně vakcinováni. V nevakcinovaných chovech byli považováni za infikované kanci s titry vyššími než 1:256. Ve vakcinovaných chovech mohli být detekováni pouze neinfikovaní kanci s titry rovnými nebo menšími než 1: 256. Infekce parvovirem prasat byla prokázána v 80,6 \% nevakcinovaných chovů. Pouze neinfikovaní kanci byli zjištěni v 18,2 \% vakcinovaných chovů. Z celkového počtu testovaných kanců v nevakcinovaných chovech (528 kusů) bylo infikováno 60,8\%. Z celkového počtu testovaných kanců ve vakcinovaných chovech (272 kusů) bylo $37,5 \%$ neinfikovaných. Výsledky práce ukazují, že je parvovirus v populacích kanců v České 
republice velice rozšîřen. S ohledem na možnost vylučování parvoviru semenem je zřejmé, že kanci mohou hrát důležitou úlohu v šíření parvovirózy v chovech prasat v České republice.

\section{References}

BOUWKAMP, F. T., WELLENBERG, G. J. 1990: The effect of parvovirus vaccination in sows through their $4^{\text {th }}$ parity and the role of influenza H1N1 virus. Tijdschr Diergeneeskund 115: 211-216

BROWN, T. T., Jr. 1981: Laboratory evaluation of selected disinfectant as a virucidal agents against porcine parvovirus, and transmissible gastroenteritis virus. Am. J. Vet. Res. 42: 1033-1036

CASTRO, J. M., DEL POZO, M., SIMARRO, I. 1992: Field trials of an inactivated virus vaccine against porcine parvovirus. J. Vet. Med. 39: 337-344

GRADIL, C., MOLITOR, T., HARDING, M., CRABO, B. 1990: Excretion of porcine parvovirus through the genital tract of boars. Am. J. Vet. Res. 51: 359-362

GRIMOLDI, F., JÁUREGUI, L. H., GUIDA, N., BARBONI de STELA, A. M., MORAS, E. V. 1998: Serological prevalence of porcine parvovirus in Argentina. Proc. 15 ${ }^{\text {th }}$ IPVS Congress, Birmingham, England, p. 44

HUYSMAN, C. N., VAN LEENGOED, L. A. M. G., DE JONG, M. C. M., VAN OSTA, A. L. M. 1992 : Reproductive failure associated with porcine parvovirus in an enzootically infected pig herd. Veterinary Record 131: $503-506$

JEŘÁBEK, J., ŠIMKOVÁ, L., MAŇOUŠKOVÁ, V., DRÁBEK, J. 1986: Porcine parvovirus vaccination (in Czech).Veterinářství 36: 55-58

KRPATA, V. 1981: Antibodies against porcine parvovirus (in Czech). Veterinářství 31: 273-284

McADARAGH, J. P., ANDERSON, G. A. 1975: Transmission of viruses through boar semen. In. Proc. $8^{\text {th }}$ Annu. Meet. Am. Assoc. Vet. Lab. Diagn., p. 69-6

MENGELING, W. L. 1999: Porcine parvovirus. In: Diseases of Swine. $8^{\text {th }}$ edn. Ed B. E Straw, S. DęAllaire, W. L. Mengeling, D. J. Taylor. Ames. Iowa. Iowa State University Press. p. 187-200

NIELSEN, J., RONSHOLT, L., SORENSEN, K. J. 1991: Experimental in utero infection of pig foetuses with porcine parvovirus (PPV). Vet. Microbiol. 28: 1-11

PAUL, P. S., MENGELING, W. L., PIRTLE, E. C. 1982 : Duration and biological half-life of passively acquired colostral antibodies to porcine parvovirus. Am. J. Vet. Res. 43: 1376-1378

PEISAK, E., VYJCIK, J. 1987: Studies into parvovirus infection of swine in Poland. Arch. Exper.Vet. Med., Leipzig 41: 894-899

PYE, D., BATES, J., EDWARDS, S. J., HOLLINGWORTH, J. 1990: Development of a vaccine preventing parvovirus-induced reproductive failure in pigs. Aust. Vet. J. 67: 179-182

SORENSEN, K. J. 1982: Porcine parvovirus: serological examination in pig breeding herds and AI boar centres. Nord. Vet. Med. 34: 329-333

SORENSEN, K. J., MADSEN, P., LEI, J. C. 1988: Efficacy of an inactivated porcine parvovirus (PPV) vaccine under field conditions. Acta vet. Scand. 29: 295-302

THACKER, B. J., LASRSEN, R. E., JOO, H. S., LEMAN, A. D. 1984: Swine diseases transmissible with artificial insemination. J. Am. Vet. Med. Assoc. 185: 511-516

THACKER, B. J., JOO, H. S., WINKELMAN, N. L., LEMAN, A. D., BARNES, D. M. 1987: Clinical, virologic, and histopathologic observations of induced porcine parvovirus infection in boars. Am. J. Vet. Res. 48: 763-767

VANNIERS, P., TILLON, J. P., CARIOLET. R., MADEC., F. 1984: Study of the efficacy of an inactivated virus vaccine against porcine parvovirus. Zentbl. Veterinärmed. 31B: 36-45 